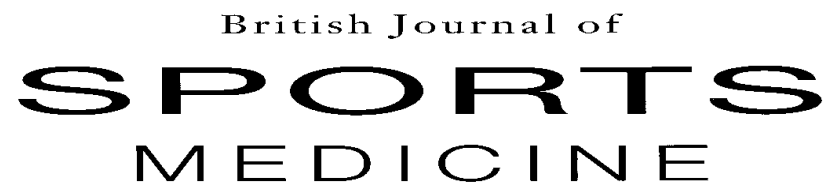

\title{
Editorials
}

Warm up

Just back from the American College of Sports Medicine (ACSM) meeting in Baltimore. The meeting once again lived up to its pre-conference hype. To attend such a conference is an eye opener. Every young sports medicine practitioner should make the effort at least once. I am sure the Americans must have some supercomputer tucked away to deal with a meeting matrix of such complexity that requires 25 concurrent sessions running at any one time. The highlight was probably the presidential keynote address on the history of medicine in space. Using more computer technology than the Apollo 11 moon landing, this talk dazzled the audience with three simultaneous data projectors, movie animation, voice overs, and sound bites from the music of the era. I pity the person designated to give the keynote at the next meeting in St Louis. How could you possibly top that performance?

One pleasing aspect is the ever increasing non-American contingent that attends this meeting. Compared with my first ACSM conference more than 10 years ago, the change is spectacular. I can well remember in Dallas (ACSM 1992) only two sports medicine clinicians from Australia preaching to the masses of sceptical Americans. I seriously believe that they thought we were actually from Austria and were surprised that we spoke English! Now the nonAmerican attendees number in the thousands. It is increasingly obvious that as more of the sports medicine organisations from around the world sponsor lectures and symposiums at this meeting, so the Americans are introduced to ideas and concepts that challenge their insular view of the world. This can only be to the advantage of all. It was impressive to see that the British Association of Sport and Exercise Medicine lecture this year was extremely well attended, and well received. Other presentations by Commonwealth, European, and Asian countries similarly served to highlight the gap that exists, particularly in clinical sports medicine, between the Americans and the rest of the world.

Apart from the programme, much of the fun of a conference such as this are the meetings and networking, which are an inevitable accompaniment of the sports medicine world. Attending four editorial board meetings, organising many other individual business and journal meetings, and catching up with friends and colleagues from all over the world can be exhausting. Once again the Friday night Commonwealth Dinner was restored to its pre-eminent position in the social programme eclipsing the formal conference dinner. If only Tom Crisp wouldn't start singing at these events!

For the first time in many meetings we actually had no professional sport being played in the conference city, with both the Orioles and the Ravens being on the road. Another attraction of the ACSM meeting is that it always falls at the time of the NBA basketball playoffs, as well as the regular baseball, and American football seasons. For a sports-mad medical audience what more could you ask? Go to a conference and see some elite sport as well. Last year in Indianapolis we had the Indiana Pacers and the NY Knicks in the NBA playoffs around the corner from the conference. The year before in Seattle we had the Mariners playing the Orioles in baseball. What a dream!

Forget Disneyworld. Forget Universal studios and Hollywood. If you get the chance, go to an ACSM meeting. Present a paper or a poster if you can. See the sights and enjoy the sport. Just do it! 


\section{Getting the British Fournal of Sports Medicine to developing countries}

For some years now it has been our policy to give gratis subscriptions to our journals to applicants from countries in the developing world. However, in practice this has had its difficulties. Many developing countries have either poor or non-existent postal services, and granting a print subscription can often be problematic and expensive- the marginal cost of sending the British fournal of Sports Medicine to Africa is around $£ 25$ each year.

An editorial in $B M F$ sets out the arguments very clearly. ${ }^{1}$ We know that the gap between the rich and poor countries is widening. Whereas those of us in the developed world have information overload, the developing countries have bare library shelves. The internet gives us the opportunity to narrow the gap.

The marginal cost of giving access to the electronic edition of the British fournal of Sports Medicine is close to zero. What is more, those in resource poor countries can access electronic journals at exactly the same time as those in the developed world. Even better, they can access what is relevant rather than what is provided, much of which is not relevant. Best of all, they can participate in the debate using the rapid response facility on the web site in a way that was almost impossible with the slowness of print distribution.

Access to the electronic edition of the British fournal of Sports Medicine will be provided free automatically to those from countries defined as poor under the human development index by the United Nations
(http://www.undp.org/hdro/HDI.html/). The BMA and several of our co-owning societies have made funds available for the installation of Digital Island on all our journal web sites. This clever piece of software recognises where the user is coming from and will give unrestricted access to the whole web site to users from those developing countries we choose to designate. BMJ.com will continue to be free to those in the developing world whatever happens in the developed world.

The income that we get from resource poor countries is minimal; and facilitating information supply should encourage development, improvement in health care, and eventually create a market.

The problem with this vision is the lack of access to the world wide web in the developing world. Whereas tens of millions of people have access in the United States, it is only thousands in most African countries; and access in Africa is often painfully slow, intermittent, and hugely expensive relative to access in the United States (where it is often free). Power cuts happen every day in many resource poor countries. Yet there is every reason to expect that access should increase dramatically. India currently has a million people with internet access, but this is expected to rise to 40 million within five years. Similarly dramatic increases are expected in Nigeria. Technological developments such as access to radio and the proliferation of satellites will render irrelevant the many problems of telephone access in Africa. Rapid progress will also be made 
because many international organisations such as Unesco, the British government, the World Bank, and the Bill and Melissa Gates Foundation are increasingly interested in helping improve information access in resource poor countries.

The challenge will be sustainability. It is easy for donors to invest money and reap the rewards of short term success, but enhancing information flow will make no impact on health if projects continue only as long as their funding lasts. Information cannot be separated from the capacity of a healthcare system to work effectively over time. How is it possible to influence the context within which information will flow, the apparently intractable political, economic, and organisational constraints that disable rather than enable information to work for people? Publishers in the rich world have a part to play, and we hope that, by making access to British Fournal of Sports Medicine online free to those in the developing world, we are making our own small contribution.

Editor

P MCCRORY

1 Godlee F, Horton R, Smith R. Global information flow. BMf 2000;321:776-7.

\section{International Symposium on Concussion in Sport}

November 2-3, 2001; Marriott Hotel, Vienna, Austria

Call for Abstracts

The International Ice Hockey Federation (IIHF) in cooperation with the Federation Internationale de Football Association Medical Assessment and Research Center (F-MARC), and the International Olympic Committee Medical Commission (IOC) is organizing an International Symposium on Concussion in Sport.

The conference will present scientific information on epidemiology, clinical science, equipment issues, long term effects, and legal aspects plus a scientific program presenting new research on concussion and head injuries, and their management and prevention. Panel discussions will conclude the symposium providing recommendations to address the concussion issue in sport for the improvement of safety and health care of athletes in all sporting fields.

\section{Speakers}

Dr Vladimir Benes (Czech Republic), Dr Robert Cantu (USA), Professor Jiri Dvorak (Switzerland), Professor Toni-Graf Baunmann (Switzerland), Dr Peter Hamlyn (England), Dr Michel D’Hooghe (Belgium), Dr Peter Jacko (Hungary), Professor Marianne Jochum (Germany), Dr Karen Johnston (Canada), Dr Barry Jordan (USA), Dr James Kelly (USA), Dr Inge Lereim (Norway), Dr Mark Lovell (USA), Professor Eric Matser (Netherlands), Dr Paul McCrory (Australia), Dr Andrew McIntosh (Australia), Dr Willem Meeuwisse (Canada), Dr Paul Piccininni (Canada), Professor B Radanov (Switzerland), and Dr Yelverton Tegner (Sweden).

Fees and contact details

Symposium registration fees: SFr 400. on or before June 15, 2001 SFr 500 after June 15, 2001. Registration fees include all symposium lectures, coffee breaks, lunch, and access to all poster and abstract presentations. An abstract submission form can be downloaded in pdf format from the IIHF web site: www.iihf.com. Submissions are requested by June 15, 2001 to: Darlene Scheurich, International Ice Hockey Federation (IIHF), Parkring 11, 8002 Zurich, Switzerland. Tel: +41 1289 8614; Fax: +41 1289 8629; email: scheurich@iihf.com. 